\title{
System Support in Counselling among Muslim Convert Clients in Malaysia
}

\author{
Samsiah Jayos ${ }^{1 *}$ \\ Faizah Abd Ghani ${ }^{2}$ \\ Lokman Mohd Tahir ${ }^{3}$ \\ Kamarul Azmi Jasmi ${ }^{4}$ \\ Nur Fatihah Abdullah Bandar ${ }^{5}$
}

1,5Universiti Malaysia Sarawak, 94300 Kota Samarahan, Sarawak, Malaysia

${ }^{2,3,4}$ Universiti Teknologi Malaysia, 81310 Skudai, Johor, Malaysia

\begin{abstract}
This study aims to identify the use of external support systems by counsellors located at the Council within the Islamic Religious Department in Malaysia. Data for this research was collected using a case study. The case study included an interview of five (5) registered counsellors in Islamic Organization in Malaysia. This study was based on a qualitative approach and data were analyzed using N'Vivo 7.0. The data were developed into appropriate themes and sub-themes. The study revealed that the external support system (community support, peer counsellor, Islamic law and Islamic organization) should be applied to Muslim counsellors and Muslim converts. This research could be used as a guide for a counsellor to be more robust in providing guidance and counselling services to specific clients, such as, new Muslim converts.
\end{abstract}

Keywords: system support; convert clients

\section{INTRODUCTION}

Malaysia is a multiracial country with a population that currently stands at 28 million of which approximately 60 percent is Muslims. Islam is constitutionally the country's

ARTICLE INFO

E-mail address:

jsamsiah@unimas.my (Samsiah Jayos)

*Corresponding author

ISSN: 2462-1153

(C) Faculty of Cognitive Sciences and Human

Development, Universiti Malaysia Sarawak (UNIMAS) official religion with the freedom to practice other religions. In Malaysia, counselling is currently gaining popularity in government organizations and the private sector. Counselling is a service available to help and support people in the process of human development in Malaysia. It has grown from a small school into a large organization (Sharif, Roslee, Sulaiman, \& Azizi, 2005). To date, the number of Muslim convert gradually increases. There are some problems faced by Muslim converts 
after their conversion to Islam. Some visible and non visible problems faced by Muslim converts include lack of knowledge, confusion and they have negative support from their surrounding (Sayyid, Mohd Syukri, \& Zawiyah, 2013). Added to this, new Muslim converts are facing vari- ous problems connected with the family, colleagues, neighbours and other people in their lives (Hidayah, Samsiah, \& Rizal, 2009).

Due to the new transition, Muslim converts need encouragement, guidance and support through counselling services.

\section{Maslow's Hierarchy Theory}

(Maslow, 1962)

This five (5) stage model can be divided into basic (or deficiency) needs;

1. Physiological

2. Safety

3. Love

4. Esteem

5. Growth needs (self-actualization)

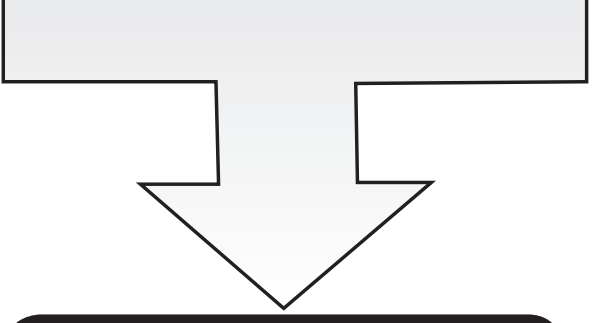

System Support in Counselling among Muslim Convert Clients in Malaysia



Figure 1: External support systems (Alken et al., 2007) and Maslow's Hierarchy Theory (Maslow, 1962) 
Samsiah Jayos, Faizah Abd Ghani, Lokman Mohd Tahir, Kamarul Azmi Jasmi, and Nur Fatihah Abdullah Bandar

Hence, they need new solutions to deal with their lives emotionally, physically, intellectually and spiritually (Cashwell, Young, \& Belaire, 2001). These Muslim converts can be helped by counsellors using the counselling approach to Islam (Loh, 2005). To ensure that clients receive the best help, registered counsellors must fully consider their professional services. Thus, counsellors who wish to practice counselling need to be registered and licensed, as advocated in Counseling Act 1998 by the counselling practitioners (Michalos, 2001; Othman, 2008).

\section{THEORIES}

In recent years, psychologists, sociologists and administrators provide various types of group support systems. This study applies Human Needs Theory in which Maslow established a form of a staircase which represents the hierarchy of needs (Ventegodt, Merrick, \& Andersen, 2003). Maslow's "theory of human motivation" was a goalbased conceptualization. An individual needs to fulfil the basic needs first, then, after satisfied, people might feel a need for love and belongingness. According to Maslow (1962), as cited in Ventegodt et al. (2003), the most difficult and rarely realized stage is self-actualization and transcendence. In this study, researchers add the element of external support systems in Alken et al. (2007) (see Figure 1). Hence, the aim of this study was to identify the use of external support systems by counsellors to assist the Muslim converts.

\section{METHODOLOGY}

The study took place in the Peninsular Malaysia, Sarawak and Sabah. The primary focus in qualitative research is to obtain rich and in-depth data. Data for this research were collected using a case study and involved five (5) registered counsellors in Islamic Organization in Malaysia. This study was based on a qualitative approach and data were analyzed using N'Vivo 7.0. Participants were new Muslim converts and they were interviewed by Muslim counsellors during their counselling sessions.

\section{RESULTS AND DISCUSSION}

The findings reveal that there are four (4) main themes: community support, peer counsellor, Islamic law, and Islamic organization (refer Figure 2).

\section{Theme 1: Community support}

In this study, community support is one of the important elements to help Muslim convert clients. This kind of support includes emergency assistance, educational assistance, and financial assistance. The support received from community includes fidyah distribution, free food, help and religious guidance (see Figure 3). This finding supports a study done by $\mathrm{Che} \mathrm{Ku}$ Shalihah (2004) which revealed that family support generally provides a good emotional impact on the new converts. $97.6 \%$ of respondents agreed that they were given the opportunity to attend courses and receive Islamic guidance. It was determined that Islamic guidance was the most helpful aid. Information about physical assistance, such as, financial aid, residence, protection and food safety are also given by the Muslims to the new converts. The respondent has a positive relationship with the Islamic community's involvement in welfare matters.

\section{Theme 2: Peer counsellor}

This study revealed that a friendly counsellor is responsible as a mentor and using counselling as one of da'wah for Islamic 


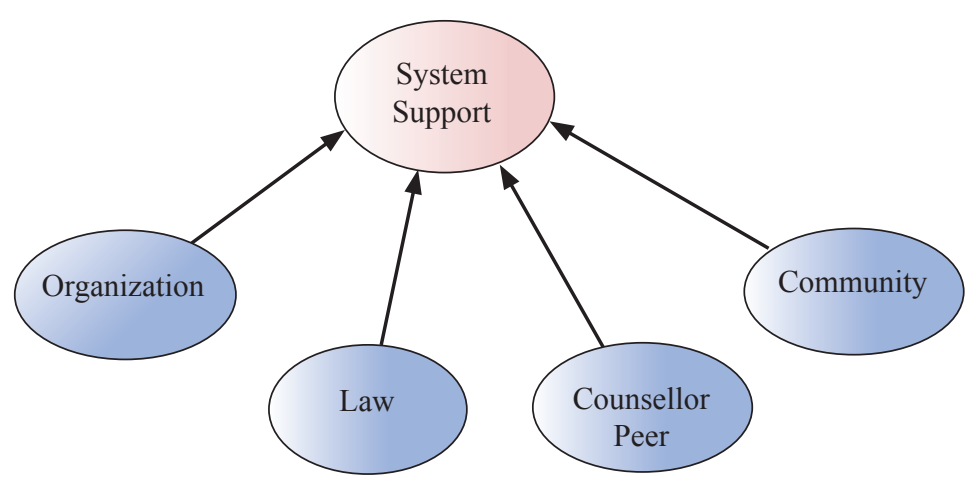

Figure 2: Model displayed as a sketch for system support

community. These approaches are highly associated with the support system in this study. There are several services and assistance received from counselling support system. The counsellor is responsible for building reciprocal trust with client through encouraging clients to express their difficulties (see Figure 3). This study is consistent with the findings by Marangu and Bururia (2012) which documented that support by the counsellor is important to help through showing positive attitude and discussing several issues pertaining health, growing up and sharing experience of the client.

\section{Theme 3: Islamic law}

The scope review as to what extent the strength of new guidance related to the contribution of law result showed that law helps Muslim converts improve their

\begin{tabular}{|c|c|}
\hline \multicolumn{2}{|l|}{ Tree Nodes } \\
\hline Name & Sources \\
\hline$\because \&$ System Support & 0 \\
\hline \multicolumn{2}{|l|}{$\$ 8$ Community } \\
\hline \& Expert Family & 1 \\
\hline$\&$ Fidyah Distribution & 1 \\
\hline \& Free Food & 1 \\
\hline 80 Help & 1 \\
\hline \& Imam & 0 \\
\hline \& Religious Guidance & 1 \\
\hline \multicolumn{2}{|l|}{$\&$ Counsellor Peer } \\
\hline$\therefore$ Counselor same races wit & 1 \\
\hline \& Discussion among counse & 1 \\
\hline + \& Muslim Counselor & 0 \\
\hline$\&$ Non-muslim Counselor & 1 \\
\hline
\end{tabular}

Figure 3: Detailed screenshot of the tree nodes for system support (Community support and Peer counsellor) 
Samsiah Jayos, Faizah Abd Ghani, Lokman Mohd Tahir, Kamarul Azmi Jasmi, and Nur Fatihah Abdullah Bandar

relationship and family life. The marital counselling (family law), spirituality counselling and post conversion problem counselling are also provided to them (see Figure 4). According to Suradi and Rafidah (2005), the government has recognized counselling as a way for a client to better relate to religion. Counselling, through guidance and legal integrity, in some ways, identifies the potential and self-development of the person. The Counsellors Act 1998 (Act 580) makes it compulsory for each counsellor to get the registration for counselling practice.

Added to this, the principles of psychological tests were conducted by a registered counsellor considering the counselling code of ethics. In order to achieve a holistic change, including an improvement and adaptation, both clients and volunteers committed themselves to change, progress and reconciliation that will persist throughout their lives. Only a strong person can embrace Islam and peace after choosing
Islam (Ariffin, 2007). Accordingly, the counsellor is required in this context to help those who are converted to Islam to be more resilient and courageous, so they can stand the test of life that is full of challenges.

\section{Theme 4: Islamic organization}

The results revealed that most respondents agreed they receive assistance in terms of Islamic religious education, guidance, counselling and moral support to help the new converts become true Muslims (see Figure 4). A study by Kassim, Abdullah, and Baba (2013) found that family disapproval also affected the muslim converted emotions. Due to this condition, Islamic organization plays an important role in providing services to muslim converts. Studies have been done about Islamic conversion and its procedures, challenges of Muslim converts, religious authorities and their responsibilities, and religious

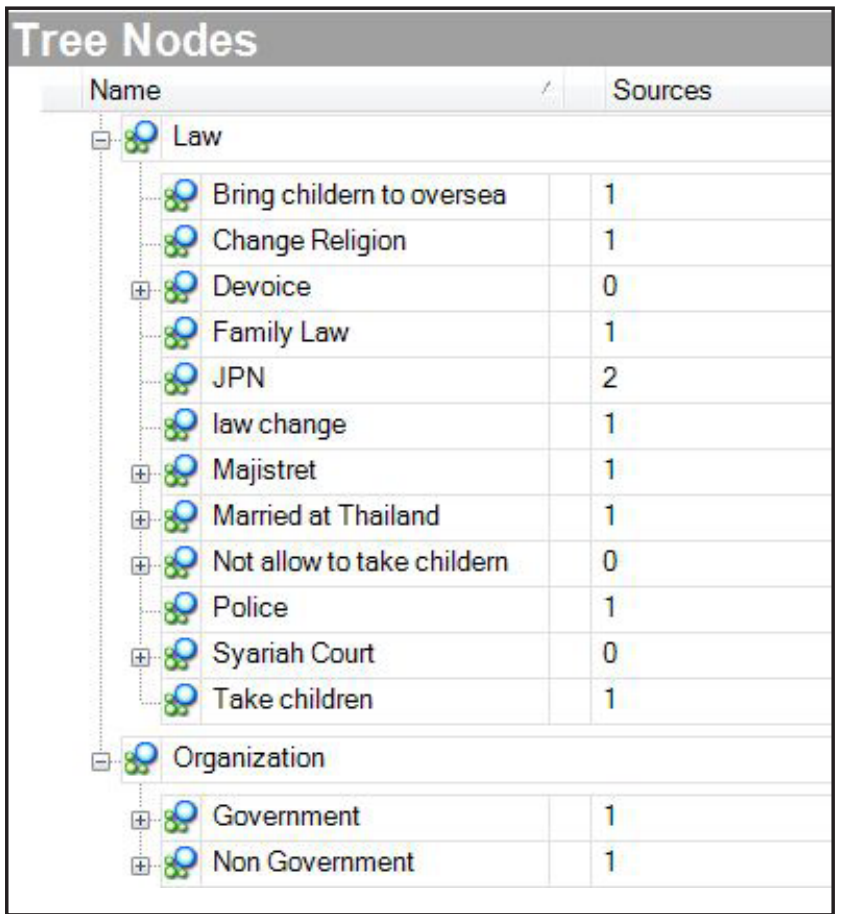

Figure 4: Detailed screenshot of the tree nodes for the system support (Islamic law and Islamic organization) 
Samsiah Jayos, Faizah Abd Ghani, Lokman Mohd Tahir, Kamarul Azmi Jasmi, and Nur Fatihah Abdullah Bandar

importance of parental and peer support for the well-being. This study is consistent with a study done by Ikhwani (2002) who asserted that new Muslim converts need guidance and support from society. Therefore, government, NGOs, public and private sectors should provide adequate support to help Muslim converts in Malaysia. Added to this, there are several organizations (for example, Ministry of Women, Family and Community Development, PERKIM, ABIM outreach and Hidayah Centre, IKRAM) that put much efforts in providing full spirituality and emotional support to Muslim converts in Malaysia (see Figure 4).

\section{CONCLUSION}

It is hoped that the finding of this study will be used by other entities. In addition, the finding on the external support system is very important to the counsellor, as a guide in providing efective and quality counselling services to new Muslim converts. In conclusion, as this study identifies the external social support (community support, peer counsellor, Islamic law, and Islamic organizations), the programs and initiatives that are highlighted are proposed to enhance persons' understanding of support system among Muslim converts in Malaysia. In addition, the data for this study were collected using a cross-sectional survey; future research is needed to obtain longitudinal data to investigate what other domains influence Muslim converts towards their post conversion. Future research could also be conducted to expand the research model by including additional domains. For example, career development among Muslim converts would be valuable in establishing the external validity of the model.

\section{REFERENCES}

Al-Ghazali (2000). Ihya' Ulum al-Din. Kitab Syarh Ajaib al-Qalb. J.2 Kaherah.

Alken, S. J., Buckland, B., Zigurs, I., \& Kathleen, E. (2007). A theory of task and group support systems effectiveness. Social Service Review, 22(3), 79-80.

Anis, H. I., \& Samsiah. J., \& Rizal, A. B. (2009). The relationship of emotional intelligence and agreeableness with help seeking behaviour as the moderating factor. Prosiding Konvensyen Isu-isu Masyarakat 2009. 4 - 5 April 2009. Fakulti Sains Kognitif dan Pembangunan Manusia (FSKPM), Universiti Malaysia Sarawak (UNIMAS), Sarawak, Malaysia.

Ariffin, S. (2007). Tauhid dalam Bible: Bible dan konsep ketuhanan. Kuala Terengganu. Universiti Darul Iman Malaysia.

Cashwell, C. S., Young, J. S., Cashwell, T. H., \& Belaire, C. (2001). The inclusion of spiritual process in counseling and perceived counselor effectiveness. Counseling and Values. 45(2), 145-146.

Che, K. S. (2004). Hubungan kekeluargaan saudara kita: Satu kajian di Darul Ukhuwah, Johor Bahru. Laporan Projek yang tidak diterbitkan. Fakulti Pendidikan, Universiti Teknologi Malaysia, Skudai Johor.

Corey, G. (2006). Theory and practice of counselling and psychotherapy $\left(7^{\text {th }}\right.$ ed.). USA: Brooks/Cole.

Creswell, J. W. (2009). Educational research: planning, conducting, and evaluating quantitative and qualitative research. New Jersey: Pearson Prentice Hall. 
Samsiah Jayos, Faizah Abd Ghani, Lokman Mohd Tahir, Kamarul Azmi Jasmi, and Nur Fatihah Abdullah Bandar

Fa'izah, P. (2004). Persepsi saudara baru tentang penerimaan masyarakat islam terhadap mereka: kajian kes di Darul Ukhuwah Johor Bahru. Laporan Projek yang tidak diterbitkan. Fakulti Pendidikan. Universiti Teknologi Malaysia, Skudai Johor.

Hairul, H. I. (2004). Persepsi pelajar spi terhadap dakwah kepada nonmuslim di kampus. Laporan Projek yang tidak diterbitkan. Universiti Teknologi Malaysia, Skudai Johor.

Ikhwani, I. (2002). Pengamalan fardhu ain saudara baru di Johor Bahru: Kajian di Unit Ukhuwah, Bahagian Dakwah, Jabatan Agama Johor. Laporan Projek yang tidak diterbitkan. Universiti Teknologi Malaysia, Skudai Johor.

Kassim, S., Abdullah, M., \& Baba, Z. (2013). A survey of problems faced by converts to Islam in Malaysia. Journal of Social Sciences and Humanities, 8(1), 85-97. Retrieved from http://www.ukm.my/e-bangi/ papers/2013/085-097.pdf.

Loh, P. F. (2005). Hubungan antara ketakutan rawatan psikologi dengan sikap mendapat bantuan kaunseling. Latihan Ilmiah yang tidak diterbitkan. Universiti Putra Malaysia, Serdang.

Malaysia (1998). Undang-undang Malaysia: Akta 580 Akta Kaunselor 1998. Tidak diterbitkan.

Marangu, P. G., \& Bururia, D. N. (2012). Challenges faced by peer counselors in their effort to effect behavior change in secondary schools in Maara District, Kenya. American International Journal of Contemporary Research, 2(11), 79-85.

Maslow, A. (1954). Motivation and personality. New York, NY: Harper.

Masrinah, M. (2008). Persepsi pelajar is- lam Fakulti Pendidikan terhadap isu penukaran agama (murtad). Laporan projek yang tidak diterbitkan. Fakulti Pendidikan, Universiti Teknologi Malaysia, Skudai Johor.

Michalos, A. C. (2001). Ethics counselors as a new priesthood. Journal of Business Ethics, 29, 3-17.

Mohammad, N. A. K. (2009). Fiqah berinteraksi dengan Non-Muslim: Kaedah bergaul dengan rakan, jiran dan keluarga bukan Islam tanpa mengabaikan syariat. Telaga Biru Sdn.Bhd. Kuala Lumpur.

Mohamed, S. M., Roslee, A., Sulaiman, S. M. N., \& Azizi, Y. (2005). Kemahiran lanjutan dalam kaunseling. Penerbit Universiti Teknologi Malaysia, Skudai Johor.

Othman, M. (2008). Amalan penyeliaan kaunseling. Penerbit Universiti Putra Malaysia, Serdang.

Samsiah, J., Faizah, A. G., \& Lokman, M. T. (2012). Tinjauan keperluan penyediaan model kaunselor saudara baru di Malaysia. Prosiding di Makassar International Research Seminar (MIRS 2012). 17- 18 Feb. 2012. Lamacca Universitas Negeri Makassar (UNM), Hotel, Makassar, South Sulawesi, Indonesia.

Sayyid, B. M. K., Mohd, S. Y. A. \& Zawiyah, B. (2013). A survey of problems faced by converts to Islam in Malaysia, E-BANGI, 8(1), 085-097.

Suradi, S., \& Rafidah, A. M. J. (2005). Development of counselling services in Malaysia. In Zafar Ansari, Noraini Noor and Amber Haque (eds.). Contemporary issues in Malaysia psychology. (pp. 23-25). Malaysia: Thompson.

Ventegodt, S., Merrick, J., \& Andersen, N. J. (2003). Quality of life theory 
Samsiah Jayos, Faizah Abd Ghani, Lokman Mohd Tahir, Kamarul Azmi Jasmi, and Nur Fatihah Abdullah Bandar

III. Maslow revisited. The Sci-

entific World Journal, 3, 1050-7.

doi:10.1100/tsw.2003.84. 